\title{
The relationship between sports sponsorship and corporate image, reputation and intention to buy: TORKU
}

\section{case}

\author{
Abdullah Sencer TEMEL ${ }^{1}$, Erkan Faruk SIRIN ${ }^{2}$ \\ ${ }^{1}$ Department of Sports Management, Institute of Health Sciences, Selçuk University, Konya, Turkey. \\ ${ }^{2}$ Department of Sports Management, Faculty of Sport Sciences, Selçuk University, Konya, Turkey. \\ Address correspondence to E. F. Sirin, e-mail: erkanfaruk@yahoo.com
}

\begin{abstract}
The purpose of this research is to examine the relationship between the recognition (being heard or not) of TORKU's (Konya Seker) sports sponsorships and image, reputation and intention to buy. In addition to this, the effects of the image the customers perceive and reputation on the buying decisions. For this purpose, the data obtained with survey method from 350 customers chosen by random sampling who shop at large shopping malls in Konya province were evaluated by descriptive, correlation and regression analysis. The scales used in the research were prepared by researches on the basis of image perception, reputation perception and intention to buy, and reliability and validity studies were carried out. As a result of the research; image perception and extent of reputation perception and intention to buy between those who heard of TORKU's sports sponsorships and those who didn't have shown the effectiveness of sponsorship activities of TORKU. Consequently, it has been demonstrated that the sports sponsorships have a positive effect on the customers, in particular TORKU customers.
\end{abstract}

Keywords: Image, intention to buy, reputation, sports sponsorships, TORKU.

\section{INTRODUCTION}

In today's competition environment, corporate reputation and image play the most important role in businesses' achieving their goals. One of the commonly used methods in creating corporate reputation and image is sponsorship activities. Taking the greatest place in sponsorship activities sports sponsorship creates opportunities for organizations aiming to promote their products to large audiences as it appeals to large audiences, is an area that draw interest and the media covers sports events. It is especially preferred by organizations and brands that want to promote their products and services to large audiences in a short time.

The concept of sponsorship, in its simplest terms is a "business agreement between two parties" (35) and in a broader sense it is evaluated as a business's financial contribution to a particular activity (sports, musical activity etc.) in order to achieve its business goals (50). The sponsor company provides money, goods, services or information, while the sponsored side (person, organization or event) offers some trade rights and partnerships for the sponsor company to use (35).
When the objectives of participating in sponsorship are studied, it is seen that there are different classifications in the literature. According to Gouguet (21), the objectives of participation in sponsorship are classified in two categories: direct and indirect. In direct objective, a rapid change is expected in the behavior of present and potential customers of the sponsoring company. In indirect objective, long-term goals such as more recognition of the two products and brands, image improvement, communication with the customer are important in addition to the sales.

With sports sponsorship activities, organizations have the opportunity to advertise in mass media, can make a positive image study, contribute to the society. As a result of this, they can improve buy behaviors of their target audience towards their products (11). "Creating an image" through sports sponsorship is one of the most impressive aspects drawing interest to this subject (53). For this reason, sports sponsorship ranks first among today's sponsorship types (63). When the numbers of most sponsored sectors are examined, sports $(84 \%)$ is first, followed by arts and culture $(6 \%)$, media $(5 \%)$, franchises $(3 \%)$ and other fields 
(2\%) respectively. Therefore, sports industry is the most sponsored sector, both in number and financially (25). Moreover, the importance of the sponsorships is predicted to increase with the sports organizations and major events in the coming years $(3,13)$. In this context, sports sponsorship is the company's use of its resources as marketing and promotional activities in the field of sports in order to achieve certain objectives (49). Therefore, sports sponsorship is often described as a strategic activity in marketing literature $(6,18,41)$. According to this, being one of the most effective tools of promotion to be used in achieving the purposes and objective stated in marketing strategies, sports sponsorship is the most preferred type of sponsorship by companies (10).

In addition, sports sponsorship is an application that adds extra value and reputation to the company as it contributes to image creation of the organization. Extra value and reputation indirectly contributes to organization's economic and marketing objectives (54). Today, businesses are allocating more and more money for sports sponsorship because of its contributions to the organization and its image. Made with such various objectives, sponsorship has increased its importance day by day and became a center of attention for companies $(53,57)$. Sponsorship examples have been one of the fastest-growing (at the global level) marketing activities in the economy for more than a hundred years, although they are relatively small and rare (36).

Today, participating in having a healthy and active image trend by undertaking sports sponsorships, organizations are able to reach different target audiences through different sports branches. When determining the sports branch to support, the target intended to achieve and the image desired to create and expected should be taken into consideration (45). In addition to these sports sponsorship automatically reinforces the reputation of an organization. Sponsorship is also a field of activity suitable for making the organization or brand image more dynamic (1).

The goodwill of the consumer while viewing the sponsorship does not only distinguish sponsorship from advertisement. Recognition, awareness, brand image and brand positioning in the mind of the target audience is aimed with sponsorship. It is seen that consumers/fans/audience that demonstrate a positive attitude and behavior towards sponsorship, also develop a positive attitude towards the sponsor brands indirectly (22)

It is not easy to transfer the intended message delivered through sponsorship activities directly to the customers. For this reason, at least basic knowledge of brand sponsors of the customers is important for delivering the said message and influencing the brand image in a positive way. Customers' having a certain level of knowledge enables organizations to use brand knowledge improved with sponsorship in a way creating value for the customers $(20,48)$. While explaining the sports sponsorship belief-attitude-hierarchy, Chen and Zhang, (8) states that positive beliefs towards the brand performing the sports sponsorship agreement becomes positive attitude towards the sponsor brand, and positive attitude becomes behaviors of buying the brand's products of using its services. According to researches, with the sports' ability to appeal large audiences worldwide and communicate easily with the target audience, it is seen that businesses show great interest in sports sponsorship to improve organization image, create brand loyalty, increase sales, attract new consumers and increase their employee's morale and motivation $(39,58)$.

Social marketing programs carried out with the perspective of sports sponsorship enable the corporate reputation and image of the business to gain value in society's eyes through raising the awareness of both the workers and the consumers. In particular, consumer masses becoming aware and raising their level of knowledge day by day in today's information economies decide buying in favor of businesses supporting sports sponsorship programs.

The question "Do recognition (being heard or not) of sports sponsorships of TORKU * (Konya Seker) have an effect on customers' image, reputation and buying behaviors?" constitutes the problem of the research. The main purpose of this research is to study the relation between the recognition (being heard or not) of sports sponsorships of TORKU (Konya Seker) and image, reputation and intention to buy. In addition to this, the effect of the image and reputation customers perceive on their decision to buy.

\section{MATERIALS \& METHODS}

The basic variables of this research which makes use of the descriptive research model are 
image, perceived reputation and intention to buy. It includes single screening model conducted with the aim to determine the formation of variables one by one, type of quantity and relational screening model (31) aimed at determining the presence and/or extent of change between two or more variables. In this study, data were collected cross-sectional with the convenience sampling method.

\section{Population and Sample}

Customers shopping at the large shopping mall in the Konya province between 15-30 November 2015 forms the population of the research. Randomly selected 400 customers form the sample of the research. A total of 400 questionnaires were distributed and 360 questionnaires returned. After the inaccurate and incomplete questionnaires were taken out, 350 questionnaires were included in the analysis.

\section{Perceived image, perceived reputation and} intention to buy Scales

Scales of perceived image (6 expressions), perceived reputation (19 expressions) and intention to buy (3 expressions) used in the research were adapted from various researches $(12,17,19,29,62)$ related to the subject.

\section{Perceived Image Scale}

In order to test the suitability of the factor model, KMO (Kaiser-Meyer-Olkin) sampling adequacy measure and Barlett $(\mathrm{p}<0.01)$ test were conducted and both tests resulted suitably. Subsequently, factor analysis was performed on 6 expressions to reveal the structural validity of the scale and to dimension the items by determining their factor loadings and a significant factor structure representing one dimension was reached. The rate of explaining the variance of this single factor is $63.000 \%$. The reliability value of the obtained scale was also found as (Cronbach $\alpha=0.882$ ).

\section{Reputation Perception Scale}

The Kaiser-Meyer-Olkin (KMO) coefficient and Bartlett Sphericity values were calculated to determine the suitability of the data before factor analysis. The KMO value was 955 and the result of the Bartlett test was (df: 171, Sig: 0.00) significant. Subsequently, factor analysis was performed to reveal the structural validity of the scale and to dimension the items by determining their factor loadings. Factor analysis with varimax rotation was performed on 21 expressions formed to define the components of the reputation perception and a significant factor structure representing 4 subdimensions was reached. To strengthen the rate of explaining the variance of these four factors, 2 items were left out of analysis considering the Communality values and varimax rotation was performed once again on 19 expression and a significant structure with four factors were reached again. The total rate of variance explain of these four factors were $69,057 \%, \mathrm{KMO}$ value was 0,955 and Bartlett's Test of Sphericity was 4419,998. The reliability value of the obtained scale was (Cronbach $\alpha=0,953$ ). When trying to name by taking the common characteristics of expressions constituting each factor into consideration, they were named as products and services (6), vision and leadership (6), social responsibility (4) and communication (3).

\section{Intention to Buy Scale}

KMO (Kaiser-Meyer-Olkin) sampling adequacy test $(0,723)$ and Bartlett $(p<0.01)$ test were carried out to test the suitability of the factor model and both test resulted suitable. Subsequently, factor analysis was performed on 3 expressions to reveal the structural validity of the scale and to dimension the items by determining their factor loadings and a significant factor structure representing one dimension was reached. The rate of explaining the variance of this factor is $81,345 \%$. The reliability value of the obtained scale was also found as (Cronbach $\alpha=0,885$ ).

\section{Statistical Analysis of Data}

The data obtained in the study was analyzed using SPSS (Statistical Package for Social Sciences) for Windows 17.0 program. Explanatory factor analysis was performed for each scale. Descriptive statistical methods (Number, Percentage, Mean, and Standard Deviation) were used while evaluating the data. For the purpose of the study, $t$ test, correlation and regression analyses among parametric tests were performed. The findings were interpreted as 95\% confidence interval at 0.05 significance level

\section{RESULTS}

In the analysis on the demographic questionnaire, the average age of the respondents was 29.8, $109(31.1 \%)$ were female and $241(68.9 \%)$ were male. The majority of participants were high school graduates $(41.4 \%)$. It was determined that 324 respondents (92.6\%) had knowledge about TORKU and 337 (96.3\%) had previously bought TORKU 
products. It was seen that with the majority rate of $(64.6 \%) 226$ of them were informed through television about the sports sponsorships of TORKU.

As it is seen from Table 1, when image perception points of the participants who heard about the various sports sponsorship activities of TORKU is compared with those who didn't, there is a significant difference except for the Konyaspor Football Team ( $\mathrm{p}=0,141 ; \mathrm{P}>0,05)$ sponsorship. Taking Konyaspor Basketball Team, Arena Football Stadium, Konyaspor Cycling Team and Arena Basketball Hall into consideration, it is understood that the difference is in favor of those who heard of the sponsorship practice. In other words, the image perception of the people who heard sponsorship activities is significantly higher than in comparison with those who didn't.

As the sub-dimension points of "products and services", "vision and leadership", "social responsibility" and "communication" regarding the participant's reputation perception of various sports sponsorship activities of TORKU is seen in table, when the points of people who heard and those who didn't is compared, it is seen that there is a significant difference except for the Konyaspor
Football Team. Taking the sub-dimension points of "products and services", "vision and leadership", "social responsibility" and "communication" regarding the participant's reputation perception of Konyaspor Basketball Team, Arena Football Stadium, Konyaspor Cycling Team and Arena Basketball Hall into consideration, it is understood that the difference is in favor of those who heard of the sponsorship practice.

As participants' intention to buy points for various sports sponsorships activities of TORKU is seen in Table 3, when the points of people who heard and those who didn't is compared, it is seen that there is a significant difference in each sports sponsorship activities. Taking image perception points of sponsorship activities of Konyaspor Basketball Team, Arena Football Stadium, Konyaspor Cycling Team and Arena Basketball Hall is taken into consideration, it is understood that the difference is in favor of those who heard of the sponsorship practice. In other words, the image perception of the people who heard sponsorship activities is significantly higher than in comparison with those who didn't.

Table 1. Comparison of image perception of people who heard of sports sponsorship activities and those who didn't.

\begin{tabular}{|c|c|c|c|c|c|c|c|c|}
\hline & Sports Sponsorship Activities & Recognition & $\mathrm{n}$ & Mean & SD & $\mathrm{t}$ & df & $\mathrm{p}$ \\
\hline \multirow{10}{*}{$\underset{\Xi}{\mathbb{U}}$} & \multirow[t]{2}{*}{ Konyaspor Football Team } & I heard & 335 & 3.81 & .97 & 1.477 & 348 & .141 \\
\hline & & I didn't hear & 15 & 3.43 & 1.31 & & & \\
\hline & \multirow[t]{2}{*}{ Konyaspor Basketball Team } & I heard & 239 & 3.94 & .92 & 3.931 & 348 & .000 \\
\hline & & I didn't hear & 111 & 3.50 & 1.06 & & & \\
\hline & \multirow[t]{2}{*}{ Arena Football Stadium } & I heard & 287 & 3.86 & .95 & 2.675 & 348 & .008 \\
\hline & & I didn't hear & 63 & 3.50 & 1.09 & & & \\
\hline & \multirow[t]{2}{*}{ Konyaspor Cycling Team } & I heard & 209 & 3.94 & .90 & 3.365 & 348 & .001 \\
\hline & & I didn't hear & 141 & 3.58 & 1.08 & & & \\
\hline & \multirow[t]{2}{*}{ Arena Basketball Hall } & I heard & 184 & 3.99 & .88 & 3.785 & 348 & .000 \\
\hline & & I didn't hear & 166 & 3.59 & 1.05 & & & \\
\hline
\end{tabular}

$\mathrm{p}<.01$ 
Table 2. Comparison of people who heard of sports sponsorship activities and those who didn't in terms of reputation perception sub-dimensions.

\begin{tabular}{|c|c|c|c|c|c|c|c|c|}
\hline Sub-Dimensions & Sports Sponsorship Activities & Recognition & $\mathrm{n}$ & Mean & S.D. & $\mathrm{t}$ & df & $\mathrm{p}$ \\
\hline \multirow{10}{*}{ 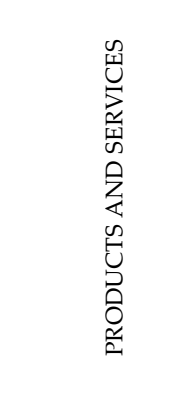 } & \multirow[t]{2}{*}{ Konyaspor Football Team } & I heard & 335 & 4.03 & .95 & 1.383 & 348 & .167 \\
\hline & & I didn't hear & 15 & 3.67 & 1.32 & & & \\
\hline & \multirow[t]{2}{*}{ Konyaspor Basketball Team } & I heard & 239 & 4.16 & .88 & 4.180 & 348 & .000 \\
\hline & & I didn't hear & 111 & 3.70 & 1.08 & & & \\
\hline & \multirow[t]{2}{*}{ Arena Football Stadium } & I heard & 287 & 4.09 & .93 & 3.151 & 348 & .002 \\
\hline & & I didn't hear & 63 & 3.67 & 1.09 & & & \\
\hline & \multirow[t]{2}{*}{ Konyaspor Cycling Team } & I heard & 209 & 4.20 & .84 & 4.423 & 348 & .000 \\
\hline & & I didn't hear & 141 & 3.74 & 1.09 & & & \\
\hline & \multirow[t]{2}{*}{ Arena Basketball Hall } & I heard & 184 & 4.18 & .83 & 3.326 & 348 & .001 \\
\hline & & I didn't hear & 166 & 3.83 & 1.08 & & & \\
\hline \multirow{10}{*}{ 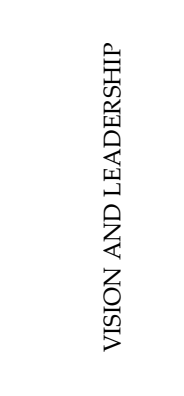 } & \multirow[t]{2}{*}{ Konyaspor Football Team } & I heard & 335 & 3.82 & .94 & .585 & 348 & .559 \\
\hline & & I didn't hear & 15 & 3.67 & 1.37 & & & \\
\hline & \multirow[t]{2}{*}{ Konyaspor Basketball Team } & I heard & 239 & 3.96 & .88 & 4.352 & 348 & .000 \\
\hline & & I didn't hear & 111 & 3.50 & 1.04 & & & \\
\hline & \multirow[t]{2}{*}{ Arena Football Stadium } & I heard & 287 & 3.87 & .94 & 2.108 & 348 & .036 \\
\hline & & I didn't hear & 63 & 3.58 & 1.01 & & & \\
\hline & \multirow[t]{2}{*}{ Konyaspor Cycling Team } & I heard & 209 & 3.91 & .90 & 2.256 & 348 & .025 \\
\hline & & I didn't hear & 141 & 3.67 & 1.02 & & & \\
\hline & \multirow[t]{2}{*}{ Arena Basketball Hall } & I heard & 184 & 3.96 & .86 & 3.017 & 348 & .003 \\
\hline & & I didn't hear & 166 & 3.65 & 1.03 & & & \\
\hline \multirow{10}{*}{ 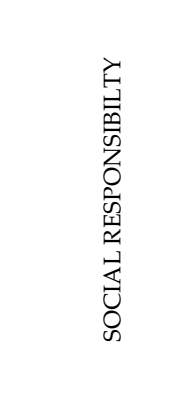 } & \multirow[t]{2}{*}{ Konyaspor Football Team } & I heard & 335 & 3.90 & .95 & 1.925 & 348 & .055 \\
\hline & & I didn't hear & 15 & 3.40 & 1.64 & & & \\
\hline & \multirow[t]{2}{*}{ Konyaspor Basketball Team } & I heard & 239 & 4.02 & .91 & 4.176 & 348 & .000 \\
\hline & & I didn't hear & 111 & 3.56 & 1.08 & & & \\
\hline & \multirow[t]{2}{*}{ Arena Football Stadium } & I heard & 287 & 3.95 & .92 & 3.048 & 348 & .002 \\
\hline & & I didn't hear & 63 & 3.53 & 1.22 & & & \\
\hline & \multirow[t]{2}{*}{ Konyaspor Cycling Team } & I heard & 209 & 4.04 & .85 & 3.826 & 348 & .000 \\
\hline & & I didn't hear & 141 & 3.63 & 1.13 & & & \\
\hline & \multirow[t]{2}{*}{ Arena Basketball Hall } & I heard & 184 & 4.08 & .84 & 4.102 & 348 & .000 \\
\hline & & I didn't hear & 166 & 3.65 & 1.09 & & & \\
\hline \multirow{10}{*}{ 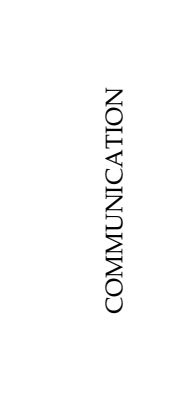 } & \multirow[t]{2}{*}{ Konyaspor Football Team } & I heard & 335 & 3.62 & 1.14 & 1.522 & 348 & .129 \\
\hline & & I didn't hear & 15 & 3.15 & 1.63 & & & \\
\hline & \multirow[t]{2}{*}{ Konyaspor Basketball Team } & I heard & 239 & 3.72 & 1.11 & 2.985 & 348 & .003 \\
\hline & & I didn't hear & 111 & 3.33 & 1.24 & & & \\
\hline & \multirow[t]{2}{*}{ Arena Football Stadium } & I heard & 287 & 3.67 & 1.13 & 2.443 & 348 & .015 \\
\hline & & I didn't hear & 63 & 3.28 & 1.25 & & & \\
\hline & \multirow[t]{2}{*}{ Konyaspor Cycling Team } & I heard & 209 & 3.77 & 1.06 & 3.357 & 348 & .001 \\
\hline & & I didn't hear & 141 & 3.35 & 1.27 & & & \\
\hline & \multirow[t]{2}{*}{ Arena Basketball Hall } & I heard & 184 & 3.75 & 1.08 & 2.545 & 348 & .011 \\
\hline & & I didn't hear & 166 & 3.43 & 1.23 & & & \\
\hline
\end{tabular}

$\mathrm{p}<.01, \mathrm{p}<.05$

Table 3. Comparison of intention to buy of people who heard of sports sponsorship activities and those who didn't.

\begin{tabular}{|c|c|c|c|c|c|c|c|c|}
\hline & Sports Sponsorship Activities & Recognition & $\mathrm{n}$ & Mean & SD & $\mathrm{t}$ & $\mathrm{df}$ & $\mathrm{p}$ \\
\hline \multirow{10}{*}{ 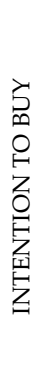 } & \multirow[t]{2}{*}{ Konyaspor Football Team } & I heard & 335 & 3.64 & 1.23 & \multirow[t]{2}{*}{2.688} & \multirow[t]{2}{*}{348} & \multirow[t]{2}{*}{.008} \\
\hline & & I didn't hear & 15 & 2.75 & 1.76 & & & \\
\hline & \multirow[t]{2}{*}{ Konyaspor Basketball Team } & I heard & 239 & 3.77 & 1.18 & \multirow[t]{2}{*}{3.632} & \multirow[t]{2}{*}{348} & \multirow[t]{2}{*}{.000} \\
\hline & & I didn't hear & 111 & 3.25 & 1.37 & & & \\
\hline & \multirow[t]{2}{*}{ Arena Football Stadium } & I heard & 287 & 3.68 & 1.25 & \multirow[t]{2}{*}{2.221} & \multirow[t]{2}{*}{348} & \multirow[t]{2}{*}{.027} \\
\hline & & I didn't hear & 63 & 3.29 & 1.30 & & & \\
\hline & \multirow[t]{2}{*}{ Konyaspor Cycling Team } & I heard & 209 & 3.76 & 1.20 & \multirow[t]{2}{*}{2.816} & \multirow[t]{2}{*}{348} & \multirow[t]{2}{*}{.005} \\
\hline & & I didn't hear & 141 & 3.38 & 1.33 & & & \\
\hline & \multirow[t]{2}{*}{ Arena Basketball Hall } & I heard & 184 & 3.80 & 1.18 & \multirow[t]{2}{*}{3.081} & \multirow[t]{2}{*}{348} & \multirow[t]{2}{*}{.002} \\
\hline & & I didn't hear & 166 & 3.39 & 1.32 & & & \\
\hline
\end{tabular}

$\mathrm{p}<.01, \mathrm{p}<.05$ 
Table 4. Comparison of people who heard of sponsorship activities and those who didn't in terms of reputation perception subdimensions.

\begin{tabular}{|c|c|c|c|c|c|c|c|c|}
\hline Sub-Dimensions & Sports Sponsorship Activities & Recognition & $\mathrm{n}$ & Mean & SD & $\mathrm{t}$ & $\mathrm{df}$ & $\mathrm{p}$ \\
\hline \multirow{10}{*}{ 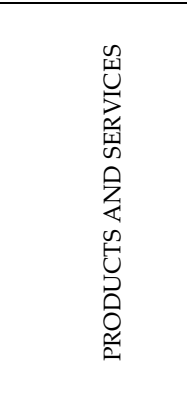 } & \multirow[t]{2}{*}{ Konyaspor Football Team } & I heard & 335 & 4.03 & .95 & 1.383 & 348 & .167 \\
\hline & & I didn't hear & 15 & 3.67 & 1.32 & & & \\
\hline & \multirow[t]{2}{*}{ Konyaspor Basketball Team } & I heard & 239 & 4.16 & .88 & 4.180 & 348 & .000 \\
\hline & & I didn't hear & 111 & 3.70 & 1.08 & & & \\
\hline & \multirow[t]{2}{*}{ Arena Football Stadium } & I heard & 287 & 4.09 & .93 & 3.151 & 348 & .002 \\
\hline & & I didn't hear & 63 & 3.67 & 1.09 & & & \\
\hline & \multirow[t]{2}{*}{ Konyaspor Cycling Team } & I heard & 209 & 4.20 & .84 & 4.423 & 348 & .000 \\
\hline & & I didn't hear & 141 & 3.74 & 1.09 & & & \\
\hline & \multirow[t]{2}{*}{ Arena Basketball Hall } & I heard & 184 & 4.18 & .83 & 3.326 & 348 & .001 \\
\hline & & I didn't hear & 166 & 3.83 & 1.08 & & & \\
\hline \multirow{10}{*}{ 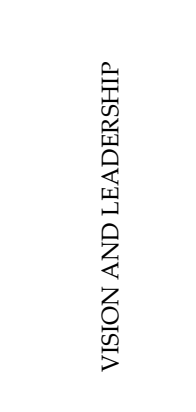 } & \multirow[t]{2}{*}{ Konyaspor Football Team } & I heard & 335 & 3.82 & .94 & .585 & 348 & .559 \\
\hline & & I didn't hear & 15 & 3.67 & 1.37 & & & \\
\hline & \multirow[t]{2}{*}{ Konyaspor Basketball Team } & I heard & 239 & 3.96 & .88 & 4.352 & 348 & .000 \\
\hline & & I didn't hear & 111 & 3.50 & 1.04 & & & \\
\hline & \multirow[t]{2}{*}{ Arena Football Stadium } & I heard & 287 & 3.87 & .94 & 2.108 & 348 & .036 \\
\hline & & I didn't hear & 63 & 3.58 & 1.01 & & & \\
\hline & \multirow[t]{2}{*}{ Konyaspor Cycling Team } & I heard & 209 & 3.91 & .90 & 2.256 & 348 & .025 \\
\hline & & I didn't hear & 141 & 3.67 & 1.02 & & & \\
\hline & \multirow[t]{2}{*}{ Arena Basketball Hall } & I heard & 184 & 3.96 & .86 & 3.017 & 348 & .003 \\
\hline & & I didn't hear & 166 & 3.65 & 1.03 & & & \\
\hline \multirow{10}{*}{ 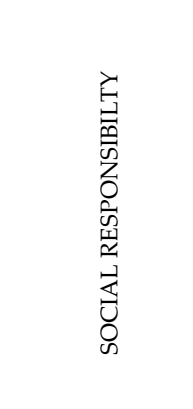 } & \multirow{2}{*}{ Konyaspor Football Team } & I heard & 335 & 3.90 & .95 & 1.925 & 348 & .055 \\
\hline & & I didn't hear & 15 & 3.40 & 1.64 & & & \\
\hline & \multirow[t]{2}{*}{ Konyaspor Basketball Team } & I heard & 239 & 4.02 & .91 & 4.176 & 348 & .000 \\
\hline & & I didn't hear & 111 & 3.56 & 1.08 & & & \\
\hline & \multirow[t]{2}{*}{ Arena Football Stadium } & I heard & 287 & 3.95 & .92 & 3.048 & 348 & .002 \\
\hline & & I didn't hear & 63 & 3.53 & 1.22 & & & \\
\hline & \multirow[t]{2}{*}{ Konyaspor Cycling Team } & I heard & 209 & 4.04 & .85 & 3.826 & 348 & .000 \\
\hline & & I didn't hear & 141 & 3.63 & 1.13 & & & \\
\hline & \multirow[t]{2}{*}{ Arena Basketball Hall } & I heard & 184 & 4.08 & .84 & 4.102 & 348 & .000 \\
\hline & & I didn't hear & 166 & 3.65 & 1.09 & & & \\
\hline \multirow{10}{*}{ 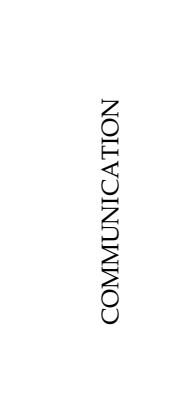 } & \multirow[t]{2}{*}{ Konyaspor Football Team } & I heard & 335 & 3.62 & 1.14 & 1.522 & 348 & .129 \\
\hline & & I didn't hear & 15 & 3.15 & 1.63 & & & \\
\hline & \multirow[t]{2}{*}{ Konyaspor Basketball Team } & I heard & 239 & 3.72 & 1.11 & 2.985 & 348 & .003 \\
\hline & & I didn't hear & 111 & 3.33 & 1.24 & & & \\
\hline & \multirow{2}{*}{ Arena Football Stadium } & I heard & 287 & 3.67 & 1.13 & 2.443 & 348 & .015 \\
\hline & & I didn't hear & 63 & 3.28 & 1.25 & & & \\
\hline & \multirow[t]{2}{*}{ Konyaspor Cycling Team } & I heard & 209 & 3.77 & 1.06 & 3.357 & 348 & .001 \\
\hline & & I didn't hear & 141 & 3.35 & 1.27 & & & \\
\hline & \multirow[t]{2}{*}{ Arena Basketball Hall } & I heard & 184 & 3.75 & 1.08 & 2.545 & 348 & .011 \\
\hline & & I didn't hear & 166 & 3.43 & 1.23 & & & \\
\hline
\end{tabular}

$\mathrm{p}<.01, \mathrm{p}<.05$

As the sub-dimension points of "products and services", "vision and leadership", "social responsibility" and "communication" regarding the participant's reputation perception of various sports sponsorship activities of TORKU is seen in table, when the points of people who heard and those who didn't is compared, it is seen that there is a significant difference except for the Konyaspor Football Team. Taking the sub-dimension points of "products and services", "vision and leadership", "social responsibility" and "communication" regarding the participant's reputation perception of Konyaspor Basketball Team, Arena Football Stadium, Konyaspor Cycling Team and Arena Basketball Hall into consideration, it is understood that the difference is in favor of those who heard of the sponsorship practice.

When the values in Table 5 are examined, it is seen that the highest mean is in the variable of products and services from the reputation perception sub-dimensions, and the lowest average is in the communication variable. In general, it is 
seen that factors are above average at the 5 point Likert scale. When the correlation values on the table are examined, it is seen that all variables are related. Intention to buy which is the dependent variant of the research, has a positive relationship with Products and Services $(r=0.439 ; \mathrm{p}<0.01)$, Vision and Leadership $(\mathrm{r}=0.467 ; \quad \mathrm{p}<0.01)$, Social Responsibility $(\mathrm{r}=0.484 ; \mathrm{p}<0.01)$ and Communication $(\mathrm{r}=0.348 ; \mathrm{p}<0.01)$ which are sub-dimensions of image $(\mathrm{r}=0.600 ; \mathrm{p}<0.01)$ and reputation perception.

Regression model made for testing the affectability of customers' intention to buy from the image perception is statistically significant $\left(\mathrm{R}^{2}=.344\right.$, $\mathrm{F}=182.849, \mathrm{p}=0.000<.05$, Table 6).

When the image perception of the customers increase by 1 unit, change of attitude increases by 0.752 unit $(\beta=0.752 ; t=13.522 ; p=0.000<0.05)$. Among the factors affecting the intention to buy, the image perception of the customer explains the intention to buy at the rate of $0.344\left(R^{2}=0.344\right)$.

Customers' intention to buy forms a significant model with the dimensions of reputation perception. Sub-dimensions of products and services, vision and leadership, social responsibility and communication explains the $24.3 \%$ of the total variance of dimension of intention to buy $\left(\mathrm{R}^{2}=.243, \mathrm{~F}=27.739, \mathrm{p}=0.00<.05\right)$. While vision/leadership and social responsibility make a significant contribution to the model, products and services, communication and communication perception alone does not make a significant contribution to the model. When vision and leadership sub-dimension, which were found significant among reputation perceptions of the customers, increases by 1 unit, change of intention to buy increases by 0.269 unit. $(\beta=0.269 ; \mathrm{t}=2.323$; $p=0.021<0.05)$. When the social responsibility subdimension, which is also significant, increases by 1 unit, the intention to buy increases by 0.285 units $(\beta=0.285 ; t=2.632 ; p=0.009<0.05$, Table 7$)$.

\section{DISCUSSION}

Sponsorship is at the forefront of most commonly used practices of public relations which provides mutual communication between the target audiences of the brand, raises awareness of the brand, creates trust, sympathy and positive image and increase the reputation. One of the most used sponsorship types within sponsorship is sports sponsorship.

Table 5. Correlation between dimensions and descriptive statistics.

\begin{tabular}{|c|c|c|c|c|c|c|c|c|c|}
\hline & & Mean & $\mathrm{SD}$ & 1 & 2 & 3 & 4 & 5 & 6 \\
\hline 1 & Buying & 3.61 & 1.27 & 1 & & & & & \\
\hline 2 & Image & 3.80 & .99 & $.600^{* *}$ & 1 & & & & \\
\hline 3 & Products and Services & 4.01 & .97 & $.439^{* *}$ & $.671^{* *}$ & 1 & & & \\
\hline 4 & Vision and Leadership & 3.82 & .96 & $.467^{* *}$ & $.725^{* *}$ & $.728^{* *}$ & 1 & & \\
\hline 5 & Social Responsibility & 3.88 & .99 & $.484^{* *}$ & $.701^{* *}$ & $.695^{* *}$ & $.755^{* *}$ & 1 & \\
\hline 6 & Communication & 3.60 & 1.16 & $.348^{* *}$ & $.619^{* *}$ & $.635^{* *}$ & $.650^{* *}$ & $.606^{* *}$ & 1 \\
\hline
\end{tabular}

Table 6. Regression model for testing the effect of perceived image on the customers' intention to buy.

\begin{tabular}{|c|c|c|c|c|c|c|c|}
\hline Dependent Variant & Independent Variant & $\beta$ & $\mathrm{t}$ & $\mathrm{p}$ & $\mathrm{F}$ & $\mathrm{p}$ & $\mathrm{R}^{2}$ \\
\hline \multirow[t]{2}{*}{ Intention to Buy } & (Constant) & .751 & 3.437 & .001 & 182.849 & .000 & .344 \\
\hline & Image & .752 & 13.522 & .000 & & & \\
\hline
\end{tabular}

Table 7. Regression model for testing the effect of sub-dimensions of perceived reputation on the customers' intention to buy.

\begin{tabular}{|c|c|c|c|c|c|c|c|}
\hline Dependent Variant & Independent Variants & $\beta$ & $\mathrm{t}$ & $\mathrm{p}$ & $\mathrm{F}$ & $\mathrm{p}$ & $\mathrm{R}^{2}$ \\
\hline \multirow[t]{5}{*}{ Intention to Buy } & (Constant) & .922 & 3.463 & .001 & & & \\
\hline & Products and Services & .138 & 1.299 & .195 & & & \\
\hline & Vision and Leadership & .269 & 2.323 & .021 & 27.739 & .000 & .243 \\
\hline & Social Responsibility & .285 & 2.632 & .009 & & & \\
\hline & Communication & -.001 & -.008 & .994 & & & \\
\hline
\end{tabular}


According to the findings obtained from the research, when the demographic characteristics of the participants are examined, the average of age is 29.8, $109(31.1 \%)$ are female and $241(68.9 \%)$ were male. Majority of the participants are high school graduates $(41.4 \%)$. It was determined that 324 (92.6\%) participants who answered the questionnaire known about TORKU and 337 (96.3\%) buy TORKU products before. It was seen that 226 $(64.6 \%)$ of them got informed about the sports sponsorships of TORKU through television. When the recognition of the participants about the sports sponsorships of TORKU is examined, Konyaspor Football Team sponsorship is at the first place with a very high level of recognition (95,7\%), Konyaspor Football Stadium sponsorship is at the second place (82\%), Konyaspor Basketball Team sponsorship is at the third place $(68,3 \%)$, Konyaspor Cycling Team sponsorship is at the fourth place $(59,7 \%)$ and Arena Basketball Hall sponsorship is at the latest place $(52,6 \%)$. When the opinions of the participants on the subject of this sponsorship activities, it can said that the recognition of Konyaspor Football Team and Konyaspor Football Stadium sponsorship is at a very high level and the recognition of Konyaspor Cycling Team sponsorship and Arena Basketball Hall sponsorship is at an average level.

According to the research findings, the image perception of the people who heard of Konyaspor Basketball Team, Arena Football Stadium, Konyaspor Cycling Team and Arena Basketball Hall among the sports sponsorship activities of TORKU except for the Konyaspor Football Team sponsorship, is significantly higher than those of who didn't. In other words, the image perception of the people who heard of sponsorship activities is significantly higher than those who didn't. No difference in image perception was found between the people who heard of Konyaspor Football Team sponsorship and those who didn't. Corporate image is the name given to the whole of the feelings, thoughts, behaviors and beliefs about the organization which is about how the internal and external target audience perceives the organization. From this point of view, corporate image has an important position in terms of leaving a positive impression on the internal and external target audience and creating credibility and trust (33). In order for a business to maintain its long-term existence, it must have a positive corporate image. It is of great importance for businesses to have a positive image, to do business for the benefit of society, to support the work done in culture-arts and social areas, and to show how sensitive the business is to these issues (5). Similar studies related to research were examined and it was seen in the results of that the recognition of sponsorship activities creates positive a positive brand image in the eyes of the target audience. Supporting the results of our research, in a study by Incereis (28) which examines the effect of 12 sponsorship activities by EFES PILSEN on the image perception, it was determined that the image perception of those who heard of sponsorship activities of the Efes Pilsen company were significantly higher than those who didn't. Tekin and Eroglu-Eskicioğlu (56) have similarly determined that when the sponsorship activities between THY and Turkish Basketball Federation is examined, sports sponsorship contributed to the brand image of Turkish Airlines. In his study, Fidan (15) saw that the target audience is aware of the various sponsorship activities of MUTLU AKÜ, they have information about most of these activities, these sponsorship activities are welcomed by the target audience and these sponsorship activities have positively contributed to the brand image. Scientific research data on sponsorship in recent years $(24,55)$ also include results that support these results in our research. Research shows that sponsorship play an important role in creating image $(9,23,32,48)$.

According to the research findings, reputation perception of people who heard of Konyaspor Basketball Team, Arena Football Stadium, Konyaspor Cycling Team and Arena Basketball Hall among the sports sponsorship activities of TORKU except for the Konyaspor Football Team sponsorship is significantly higher than those who didn't in "products and services", "vision and leadership", "social responsibility" and "communication" dimensions of reputation perception.

When the dimension of products and services is examined, it was determined that the attitude of people who heard of sponsorship activities towards the quality of products and services was significantly higher than those who didn't. In other words, the reputation perception of people who heard of sponsorship activities is significantly higher than those who didn't hear of products and services. For a product and service to brand, it is first necessary to keep the reputation of that product and service to alive in the minds of consumers. And for this, companies can ensure it's alive with marketing 
communication activities such as sponsorship. Sponsorship endeavor to make customers loyal by keeping them updated on the brand, products and services. It carries out the communication activities required for this. This is only one of the communication purposes of sponsorship. In addition, sponsorship affects the attitude of consumers regarding the products and services or endeavors to reinforce the positive attitude or make negative attitude into positive. Sponsorship makes consumers show interest in products, services or brand and after they are interested, it makes them have a desire to possess the product, service or brand (14). According to Bulbul (7), one of the objectives of organizations engaging in sponsorship activities is to convince consumers to buy the products and services of the organization, attract attentions and interests of the consumers. Businesses facilitate the buy of their products and services by attracting the interest and attention of the target audience (60). In this regard, consumers pay attention to the social responsibilities of the brand as well as the benefits the brand offers to them in the promotion activities they make about their products and services. Consumers have also evolved into an audience who examines and inquires the messages delivered to them by the manufacturer companies.

When the dimension of vision and leadership is evaluated, it was determined that vision and leadership perceptions of people who heard of sponsorship activities are significantly higher than those who didn't. Perceptions of participants such as "It has perfect leadership", "It has an open vision for the future", "It recognizes the market opportunities and makes use of them" are higher in those who heard of TORKU's sponsorship activities. It can be said that these sponsorship activities affect vision and leadership perceptions towards TORKU positively. In the study of Incereis (28) which supports or research findings, it was determined that the dimension of vision and leadership perception of people who heard of sponsorship activities of EFES PILSEN are significantly higher.

When the dimension of social responsibility is evaluated, it was determined that social responsibility perceptions of people regarding TORKU who heard of sponsorship activities are significantly higher than those who didn't. Perceptions of participants such as "It supports social events that are helpful", "It is responsibilities against for the environment", "It has good human relationships" are higher in those who heard of TORKU's sponsorship activities. The general acceptance of businesses by the society depends on meeting the needs and requirements of target customer groups and showing social responsibility (4). In the study of Incereis (28) which supports or research findings, it was determined that the dimension of social responsibility perception of people who heard of sponsorship activities of EFES PILSEN (Efes Blues Festival, One Love Festival, IKSV International Film Festival, Efes Pilsen Basketball Club, Efes Pilsen Cup (football organization), Turkish National Team sponsorship, Efes Dark Roxy Music Days and Rock'n Dark Music Competition) are significantly higher.

When the dimension of communication is evaluated, it was determined that communication perceptions of people regarding TORKU who heard of sponsorship activities are significantly higher than those who didn't. Corporate reputation is a strategic asset. This asset loses value if a correct and continuous communication is not ensured. Continuous value increase can be achieved with communication activities. As sponsorships contribute to the reputation by means of communication activities and interactive relations, a good reputation makes sponsorship activities to increase (28). As it is seen with these explanations, communication dimension perceptions within the reputation perceptions of people who heard of sponsorship activities of TORKU are higher. For this reason, it is necessary for organizations to offer the communication strategies and materials to the target audiences in the best way and plan well at all stages of sponsorship process (44). Thus, with the sponsorship activities, it will be ensured that the organization achieves its objectives in terms of public relations, increases the reputation of the organization and it is supported. In this context, perceptions of the target audience towards the organization will change positively (43).

According to the research findings, the intention to buy points of people who heard of Konyaspor Football Team, Konyaspor Basketball Team, Arena Football Stadium, Konyaspor Cycling Team and Arena Basketball Hall among the sponsorships of Turkey are significantly higher. In other words, the reputation perception of people who heard of sponsorship activities is significantly higher than those who didn't. Attitudinal reasons are also important in decisions to buy, as well as 
palpable reasons such as price and quality. The ego, emotional tendency and requirements of the individual are the determinants of the product she/he buys. Sponsorships aim to change the attitudes of consumers towards buying as well as their attitude towards the brand. The most important outcome of sponsorship activities is creating positive brand attitude and affecting the intention to buy positively. Therefore, as proposed in this study, recognition of sponsorship activities can affect the intention to buy the product positively. It is stated high acceptability or recognition makes both perceptions of the customers towards brand and their intention to buy change in a positive way $(2,26,34)$ requirements of target customer groups and showing social responsibility (4). In the study of Incereis (28) which supports or research findings, it was determined that the people's intention to buy who heard of sponsorship activities of EFES PILSEN (Efes Blues Festival, One Love Festival, IKSV International Film Festival, Efes Pilsen Basketball Club, Efes Pilsen Cup (football organization), Turkish National Team sponsorship, Efes Dark Roxy Music Days and Rock'n Dark Music Competition) are significantly higher. In the study of Akyildiz \& Marangoz (1), it was concluded that, when the consumers who were the least affected by the sponsorship activities are taken as reference, the partially affected individuals were less interested in sports and sports activities than the completely affected individuals. That is, as the interest in sports decreases, the effect of sponsorship activities on decisions to buy also decreases. This result partially supports our study. Another study made in the past shows that high identification also affects attitudes towards sponsor brands. With sports sponsorship activities, organizations get the opportunity to promote in mass communication, make a positive image study, contributes to the society. And as a result of this, they can improve their target audience's buying attitudes (19). In his study, Irwin et.al (26), found that cause-related marketing strategies (e.g. sports themed sponsorships) affects the intention to buy the brand in favor of the brand. He also stated that consumers' attitude towards sports themed cause-related sponsorships is in favor of the brand and they have the potential to affect the first impression on the consumer positively. The study by Miloch \& Lambretch (37) of the sponsorship of sportive events to determine the effects on customer awareness has shown that the high level of interest shown against any event increases the intention to buy.

According to findings reached as a result of correlation analysis, main variables of image and reputation perception (products and services, vision and leadership, social responsibility and leadership) affect the intention to buy positively. The findings in question show that the intention to buy and image are related at the maximum level. This means that the higher the brand image, the higher the intention to buy. This result shows that it would be beneficial for businesses to engage in sponsorship activities by taking perceived image into consideration. From this point of view, it can be said that as consumers knows about the sponsorship activities of the brand, their positive attitude towards the brand increases and this also increases the buy the brand image and the intention to by (51). The studies on sponsorship show that the brand image affects the sponsorship success $(9,23,32,48)$. In addition to this, the social responsibility perception comes first among the main variants of reputation perception affecting the intention to buy again in the positive direction. This is followed by vision and leadership, products and services and communication perception respectively.

As a result of the regression analyses made, it was seen that harmony for both models were provided. First one of these was regression model made to test the affectability of the intention to buy by image perception. According to this model, there is a positive correlation with the reputation perception and the intention to buy. In addition to this, image perception of the consumer explains 34\% of the intention to buy. In sponsorship activities, intention to buy is realized with the increase of brand image $(16,30,42)$. The results also support this statement. In other words, increasing brand image means increasing possibility of consumers' buying the brand. In their studies Koo et al. (32), who support our findings, states that sponsorship activities raises the awareness of consumers regarding the brand, corporate image and brand awareness and that these factors are factors of the intention to buy. In a similar study, Pope and Voges (46) found a strong relationship between the tendency to buy and sponsorship of businesses, business image and the brand itself. Again, Speed and Thompson (52) state that the more positive the perceptions of customers regarding the sponsor brand, the higher the positive effect of them on the 
brand after the sponsorship. Due to the increasing positive image, there will be an increase in the consumers' tendency to buy the brand.

Second model of the research is the regression model to test the affectability of the intention to buy by the dimension of reputation perception. According to this model, there is a positive correlation with the reputation perception and the intention to buy. In addition to this, products and services and communication perceptions which are subdimensions of consumer's perception, explain $24 \%$ of the intention to buy, even though they don't contribute significantly to the model. The most effective reputation perception on the intention to buy was determined as the social responsibility variable. In addition to this vision and leadership reputation perception as well predict the intention to buy. Turkmen et al (60), who support our findings on the relationship between the social responsibility and the intention to buy, corporate social responsibility factors (legal and ethical responsibility, economical responsibility and philanthropic responsibility) explain $24 \%$ of the intention to buy in their study aiming to examine the relationship between the concept of corporate social responsibility and consumer's intention to buy. In his study on 213 Turkish students who study at state and foundation universities Yavuz (61) stated that university students "sometimes" socially responsible buying behaviors and prefer to buy products of companies who show corporate philanthropy rather than those of who don't, even though they are $10 \%$ more expensive. Similarly, the study of Mohr and Webb (36) also show that corporate social responsibility can affect the buying behavior. In addition, research company MORI found out that while buying a product, $70 \%$ of Europeans attach importance to social responsibility activities in terms of organizational commitment and one in every five people are ready to pay more for products that are socially and environmentally responsible (47). Another finding of the MORI is that consumer in United Kingdom (England, Scotland, and Wales) find social responsibility activities are very important in choosing their products and reports that the number which was $28 \%$ in 1998 went up to $46 \%$ in 2001 (40). In his research on the Vestel example, Ibisoglu (27) determined that corporate social responsibility is the third factor affecting the buying behavior after the price and product quality. Based on the finding that social responsibility affects the intention to buy at the highest level, these types of organizations should organize social responsibility events so that they can gain sufficient reputation. They can also gain the difference of distinguish themselves from their competitors by organizing these events or sponsoring the organized events (11).

As a result, it is evaluated that, as there is a relationship between sports sponsorships and corporate image, reputation, and the intention to buy and there were no other studies on the subject, the study can be helpful to the literature in this respect. The prominent result of the research is that almost all of the sample group know TORKU. The fact that TORKU is the sponsor of Konyaspor Football Team is known with the very high percentage of $95.7 \%$. Customers' image perception, reputation perception and intention to buy regarding TORKU were significantly higher in people who know about sports sponsorship of TORKU compared to those who don't. The result of the regression analysis also showed that the image and reputation perceptions of TORKU customers cause positive change of buying behavior.

\section{Limitations of the Research and Suggestions for Future Researches}

Limitations of the research are use of convenience sampling method, instantaneous collection of the data and that it consists of customers who are shopping at shopping malls in the Konya province only. Future studies can be made on target active audiences, audiences and media audiences of sponsorship activities on a larger area and a larger sample group. This research was conducted on people residing in Konya province. From this point, it is evaluated that researches in the future can be conducted on people residing in different parts of Turkey. Findings that will be recorded as a result of a further research with a larger scope are expected to be helpful in terms of developing effective marketing strategies for sponsor companies.

\section{AKNOWLEDGEMENT}

The paper was presented orally at the 1 th International Management Research Congress, 19-20 March, Ankara, Turkey.

\section{REFERENCES}

1. Akyıldız M, Marangoz M. Reflecting of sport sponsorships to consumer's buying intent. Ege Academic Review, 2008; 8(1): 153-166. 
2. Alexandris K, Tsaousi E, James J. Predicting sponsorship outcomes from attitudinal constructs: the case of a professional basketball event. Sport Marketing Quaterly, 2007; 16(3): 130-139.

3. Argan, M. Spor Sponsorluğu Yönetim Sürecine Kavramsal Yaklaşım, 7. Uluslararası Spor Bilimleri Kongresi, 27-29 Ekim, Kemer-Antalya, 2002.

4. Arslan M, Gegez AE, Gurdal S. Kurumsal kimlik, kurumsal imaj markanin yansitıcisı midır?", 6.Ulusal Pazarlama Kongresi, 28 Haziran - 1 Temmuz, Atatürk Üniversitesi, Erzurum, 2001.

5. Bolat Oİ. The process of creating a corporate image in lodging establishments. Balıkesir University Journal of Social Sciences Institute, 2006; 9(15): 108-126.

6. Carter DM. Keeping score: An inside look at sports marketing, Oasis Press/PSI research, Grants Pass. OR. 1996.

7. Bülbül AR. Halkla İlişkiler, Ankara: Nobel Yayınları, 2004.

8. Chen K, Zhang J. Examining consumer attributes associated with collegiate athletic facility naming rights sponsorship. Development of a theoretical framework. Sport Management Review, 2011; 14:103-116.

9. Chien PM, Cornwell, TB, and Pappu R. Sponsorship portfolio as a brand image creation strategy. Journal of Business Research, 2011; 64:142-149.

10. Covell D. The Lowell spinners and the Yankee elimination project: A case study consideration of linking community relations and sponsorship. Sport Marketing Quarterly, 2008 17(2): $122-126$

11. Çölgeçen BA. Culture and art sponsorship in Turkey: problems and solution suggestions based on the samples of Türkiye İş Bankasi, Efes Pilsen and Türsak. Doctoral Thesis, Institute of Social Sciences, Selcuk University, Ankara, 2008.

12. Dees W, Bennett G, Villegas J. Measuring the effectiveness of sponsorship of an elite intercollegiate football programme. Sports Marketing Quarterly, 2008; 17(2): 79-89.

13. Demirel A, Erdoğmuş IE. Corporate investment in spor sponsorhip and its evaluation. Athens Journal of Sports. 2014 1(3): 173-187.

14. Erdem A. Tüketici Odaklı Bütünleşik Pazarlama İletişimi. Ankara: Nobel Yayın Dağıtım, 2006.

15. Fidan Z. The importance of sponsorship in corporate image. Master Thesis, Institute of Social Sciences, Selcuk University, Ankara, 2009.

16. Flavian C, Torres E, Guinaliu M. Corporate image measurement: A further problem for the tangibilization of internet banking service. The International Journal of Bank Marketing, 2004; 22(5): 447- 470.

17. Fombrun CJ. Reputation: Realizing Value from the Corporate Image. Boston, Harvard Business School Press, 1996.

18. Gilbert D. Sponsorship strategy is adrift. The Quarterly Review of Marketing, 1988; 14: 6-9.

19. Gray ER, Balmer JMT. Managing corporate image and corporate reputation. Long Range Planning, 1998; 31: 695-702.
20. Grohs R, Wagner U, Vsetecka S. Assessing the effectiveness of sport sponsorships: An empirical examination. Schmalenbach Business Review, 2004; 56: 119-138.

21. Gouguet JJ. In W Andreff, S Szymanski (Eds). Handbook on the Economics of Sport (pp.71-72). Cheltenham: Edward Elgar Publishing Ltd. 2006.

22. Gümüş S, Erdem B. The impact of sport sponsorship on attitudes of customers, an application to customers of airlines. International Anatolia Academic Online Journal, 2014; 2(1): 125

23. Gwinner KP, \& Eaton J. Building brand image through event sponsorship: The role of image transfer. Journal of Advertising, 1999; 28(4): 47-57.

24. IEG (International Events Group). Sponsorship spending report. $\quad$ Retrieved from http://www.sponsorship.com/IEG/files/4e/4e525456-b2b14049-bd51-03d9c35ac507.pdf, 2015.

25. IFM. The World Sponsorhip Monitor, TWSM, Annual Review. ABD, 2011

26. Irwin RL, Lachowetz, T, Cornwell TB, Clark JS. CauseRelated sport sponsorship: An assessment of spectator beliefs, attitudes, and behavioral intentions. Sport Marketing, 2003; 12(3): 131-139

27. İbişoğlu A. Corporate social responsibility: Vestel case, Master Thesis, Institute of Social Sciences, Başkent University, Ankara, 2007.

28. Incereis Ö. Sponsorship activities relationship with corporate reputation and an example of Efes Pilsen. Master Thesis, Institute of Social Sciences, Marmara University, İstanbul, 2011.

29. Javalgi RG, Taylor BM. Traylor, Gross AC, Lampman E. Awareness of sponsorship and corporate image: An empirical investigation. Journal of Advertising, 1994; 23(4): 47-58.

30. Kandampully J, Suhartanto D. Customer loyalty in the hotel industry: The role of customer satisfaction and image. International Journal of Contemporary Hospitality Management, 2000; 12(6); 346- 351.

31. Karasar N. Bilimsel Araştırma Yöntemi. Ankara: Nobel Yayın Dağıtım, 2009.

32. Koo GY, Quarteremani J, Flynn L. Effect of perceived sport event and sponsor image fit on consumers' cognition, affect, and behavioral intentions. Sport Marketing Quarterly, 2006; 15(2): 80-90.

33. Küçük F. Institutional communication from perspective of corporate image. Research of Eastern Anatolia Region, 2005; 3(2): 45-52

34. Lafferty BA. The relevance of fit in a cause- brand alliance when consumers evaluate corporate credibility. Journal of Business Research, 2007; 60(5): 447-453.

35. Lagae W. Sports Sponsorship and Marketing Communication: A European Perspective, Harlow, FT Prentice Hall, 2005.

36. Meenaghan T. Understanding sponsorship effects, Psychology \& Marketing, 2001; 18(2): 95-122. 
37. Miloch KS, Lambrecht KW. Consumer awareness of sponsorship at grassroots sport events. Sport Marketing Quarterly, 2006; 15(3): 147-154.

38. Mohr AL, Webb JD. The effects of corporate social responsibility and price on consumer responses. The Journal of Consumer Affairs, 2005; 39(1): 121-147.

39. Odabaşı Y, Oyman M. Pazarlama İletişimi Yöntemi. İstanbul MediCat Kitapları, 2007.

40. Oppewal H, Alexander A, Sullivan P. Consumer perception of corporate social responsibility in town shopping evaluation. Journal of Public Affairs, 2005; 6: 5-12.

41. Otker T. The key to sponsorship success. European Research, 1988; 16(2): 77-86.

42. Özer A. The effect of attitude towards brand on brand image and purchase intention after sponsorship, Hacettepe University Journal of Economics and Administrative Sciences, 2011; 29(2): 145-174

43. Özkan A. Halkla İlişkiler Yönetimi. İstanbul: İstanbul Ticaret Odası Yayınları, 2009.

44. Özkoç B. The role of corporate communication in creating corporate citizenhip in business enterprieses. Master Thesis, Institute of Social Sciences, Ege University, İzmir, 2012

45. Peltekoğlu FB. İmajın Çekiciliği mi, Sokrates'in İtibarı mı?, Tüm Yönleriyle Halkla ilişkiler ve Tanıtım Eğitim Kitabevi, Konya, 2007.

46. Pope NK, Voges KE. The Impact of sport sponsorship activities, corporate image, and prior use on consumer purchase intention. Sports Marketing Quarterly, 2000; 9(2), 96-101.

47. Pomering A, Dolnicar S. Customers' sensitivity to different measures of corporate social responsibility in the Australian banking sector. Journal Business Ethics, 2006; 69(2): 205-215.

48. Roy D, Cornwell B. Brand equity's influence on responses to event sponsorships. Journal of Product \& Brand Management, 2003; 12(6): 377-393.

49. Shank D. Sports Marketing - A Strategic Perspective. New Jersey: Prentice-Hall Inc. 1999.

50. Simmons CJ, Becker-Olsen KL. Achieving marketing objectives through social sponsorships. Journal of Marketing, 2006; 70(4): 154-169.
51. Spears N, Singh SN. Measuring attitude toward the brand and purchase intentions. Journal Of Current Issues \& Research In Advertising (CTC Press), 2004; 26(2); 53-66.

52. Speed R, Thompson P. Determinants of sports sponsorship response. Journal of the Academy of Marketing Science, 2000; 28(2); 226-238.

53. Soyer F. Sporda Sponsorluk: Kavram, Kapsam ve Bir Araştırma. Ankara: Gazi Kitabevi, 2003.

54. Tavlak S. The impact of art sponsorship on corporate reputation. Master Thesis, Institute of Social Sciences, Marmara University, İstanbul, 2007.

55. Theaker A. Halkla İlişkiler El Kitabı. İstanbul: MediaCat Kitapları, 2006.

56. Tekin N, Eroğlu Eskicioğlu Y. Sports sponsorship: Turkish Airlines - Turkish Basketball Federation sample. Spor Yönetimi ve Bilgi Teknolojileri Dergisi, 2015; 10(1): 14-36.

57. Tezcan K. The importance and tax aspects of the importance and tax aspects of sponsorship expenditures. Mali Çözüm Dergisi, 2006; 78: 95-116.

58. Türegün E. Sports organizations sponsorship (Example of BEKO basketball league). Doctoral Thesis, Institute of Healthl Sciences, Marmara University, İstanbul, 2013.

59. Türkmen MS, Pirtini S, Bayraktar A, Bilgen İ. A research on relationship between corporate social responsibility and consumer purchase intention. Marmara Üniversitesi Öneri Dergisi, 2016; 12(45); 375-392.

60. Yavuz C. Halkla İlişkiler. Ankara: Detay Yayıncılık, 2006.

61. Yavuz Ş. The effects of corporate social responsibility on corporate image and purchase decision. Journal of Selcuk Communication, 2010; 6(3): 100-110.

62. Whitlark DB, Geurts MD, Swenson MJ. New product forecasting with a purchase intention survey. The Journal of Business Forecasting Methods Systems and Systems, 1993; 12(3); 1-18.

63. http://www.sponsorship.com/Resources/What-SponsorsWant-and-Where-Dollars-Will-Go-in-20.aspx erişim: (Erişim: 18.01.2017).

\footnotetext{
* Although TORKU is a new brand, which said 'hello' to the consumers in 2007,it emerged with the efforts of 900 thousand producing partners on accumulation of 63 years of Konya Seker, which is a producer's cooperative. Konya Seker created a great system, whose steps it keeps under control from seed to package to offer 100 percent natural, trustworthy and quality products to its consumers.
} 